\title{
FAKTOR-FAKTOR YANG MEMPENGARUHI MOTIVASI WISATAWAN MANCANEGARA BERKUNJUNG KE PURA PUSEH DESA ADAT BATUAN, GIANYAR
}

\author{
Kadek Sandra Putri Dewanti ${ }^{1}$, I Made Sendra ${ }^{2}$, IGPB Sasrawan Mananda ${ }^{3}$ \\ ${ }^{1}$ Email: sandraputri11@yahoo.com \\ Program Studi S1 Industri Perjalanan Wisata, Fakultas Pariwisata, Universitas Udayana \\ 2Email: sendramade65@gmail.com \\ Program Studi S1 Industri Perjalanan Wisata, Fakultas Pariwisata, Universitas Udayana \\ ${ }^{3}$ Email: gusmananda@yahoo.com \\ Program Studi S1 Industri Perjalanan Wisata, Fakultas Pariwisata, Universitas Udayana
}

\begin{abstract}
The purpose of this research is to know the potential of Puseh and Desa Temple at Batuan Village as a tourist destination and the factors that influence the motivations of foreign tourists visiting those temple. This research was using quantitative descriptive supported by SPSS Version 17.0. The result showed that Puseh and Desa Temple at Batuan Village have a cultural potency to be a tourist destination for foreign tourist visiting those temple. The tourists are dominated by female, the age of tourists are dominated by 25-44 years old and the nationality of foreign tourists are dominated by Australian. According to the validity and reliability test of 18 variables showed that all of the variables are valid and reliable. Accordingly, the variables could be proceeded to the factor analyze. According to the factor analyze test, there are three factors that influence the motivations of foreign tourists visiting Puseh and Desa Temple at Batuan Village, such as 1) The pull factors involved culture uniqueness, historical heritage, arts, custom, new experiences, comfortable, seeing the local peoples preparing the small offerings, easy to access and physiological satisfaction. 2) The promotion factors involved influence of family, influence of co-workers, information from travel agent and information from internet. 3) Push factors involved prestige, temple structure, social interaction, influence of friends and escape as well.
\end{abstract}

\begin{abstract}
Abstrak: Tujuan dari penelitian ini adalah untuk mengetahui potensi-potensi yang dimiliki oleh Pura Puseh Pura Desa Adat Batuan, Gianyar dan faktor-faktor yang mempengaruhi motivasi wisatawan mancanegara berkunjung ke pura tersebut. Penelitian ini menggunakan teknik analisis deskriptif kuantitatif dengan uji validitas, reliabilitas dan analisis faktor yang dibantu dengan program SPSS Versi 17.0. Hasil dari penelitian ini menunjukkan bahwa Pura Puseh Pura Desa Adat Batuan memiliki potensi budaya yang menjadi salah satu daya tarik wisatawan berkunjung ke pura tersebut. Wisatawan yang berkunjung didominasi oleh wisatawan perempuan dan wisatawan berumur 25-44 tahun. Negara asal yang paling mendominasi yaitu Australia. Berdasarkan uji validitas dan reliabilitas pada 18 subindikator dengan program SPSS semua variabel dinyatakan valid dan reliable, sehingga dapat dilanjutkan ketahap analisis faktor. Berdasarkan hasil uji dari analisis faktor terdapat tiga faktor yang mempengaruhi motivasi wisatawan mancanegara berkunjung ke Pura Puseh Pura Desa Adat Batuan Gianyar yaitu 1) Faktor penarik: (a) keunikan budaya, (b) peninggalan bersejarah, (c) kesenian, (d) adat istiadat, (e) pengalaman baru, (f) kenyamanan, (g) melihat masyarakat lokal membuat sesajen, (h) mudah diakses, (i) kepuasan psikologis. 2) Faktor promosi yaitu: (a) pengaruh keluarga, (b) pengaruh rekan kerja, (c) informasi dari travel agent, (d) informasi dari internet. 3) Faktor pendorong yaitu: (a) gengsi, (b) struktur pura, (c) interaksi sosial, (d) pengaruh teman, (e) melepaskan diri dari lingkungan yang dirasakan menjemukan (escape).
\end{abstract}

Keywords: the potential of puseh and desa temple at batuan village, tourist motivations, and factor analyze. 


\section{PENDAHULUAN}

Pariwisata merupakan suatu kegiatan yang dilakukan oleh seseorang atau kelompok yang berpindah-pindah dari satu tempat ke tempat lainnya dengan suatu perencanaan atau bukan maksud untuk mencari nafkah di tempat yang dikunjunginya, dalam kurun waktu sementara yang bertujuan hanya semata-mata untuk mencari hiburan dan berlibur dari kegiatan sehari-hari yang membuat lelah atau penat.

Seseorang atau kelompok yang melakukan kegiatan perjalanan wisata disebut dengan wisatawan. Dalam melakukan perjalanan wisata, wisatawan pasti memiliki motivasi pejalanan. Motivasi merupakan faktor penting bagi calon wisatawan di dalam mengambil keputusan mengenai daerah tujuan wisata yang akan dikunjungi. Calon wisatawan akan mempersepsikan daerah tujuan wisata. Persepsi ini dihasilkan oleh preferensi individual, pengalaman sebelumnya, dan informasi yang didapatkannya (Pitana, 2005 : 60). Menurut Sharpley dan Wahab (dalam Pitana, 2005 : 58), motivasi merupakan hal yang sangat mendasar dalam studi tentang wisatawan dan pariwisata, karena motivasi merupakan pemicu dari proses perjalanan wisata, walaupun motivasi ini sering tidak disadari secara penuh oleh wisatawan itu sendiri.

Motivasi wisatawan untuk mengunjungi suatu daerah sangat beragam. Ditinjau dari aspek sifatnya maka setiap wisatawan memiliki motivasi umum dan motivasi khusus. Motivasi perjalanan dikatakan umum apabila motivasi ini mendorong seseorang hanya sekedar untuk beralih tempat. Suatu motivasi menjadi khusus atau selektif bilamana wisatawan terdorong untuk mengunjungi suatu objek wisata atau negara tertentu untuk menikmati atraksi wisata yang ada pada daerah tersebut. Motivasi yang spesifik seperti halnya motivasi umum akan berbeda dari satu orang dengan lainnya. Semuanya bermuara pada faktor apa yang mendorong wisatawan berkunjung ke suatu destinasi wisata tersebut (Murphy dalam Widyastuti et al $2017: 30$ ).

Ada beberapa faktor-faktor yang mempengaruhi wisatawan untuk melakukan suatu perjalanan wisata. Dari sekian banyak wisatawan yang melakukan perjalanan wisata beberapa dari mereka semata-mata melakukan perjalanan wisata untuk mencari hiburan dan bersenang-senang seperti tujuan wisata pada umumnya. Namun, beberapa dari wisatawan baik domestik maupun mancanegara melakukan perjalanan wisata untuk menambah wawasan, pengetahuan, memenuhi rasa ingin tahu mereka dan keterampilan dalam suatu hal. Wisatawan datang ke suatu tempat atau destinasi wisata tidak cukup hanya untuk melihat-lihat kegiatan yang terjadi di daerah tujuan wisata yang mereka kunjungi, namun ada beberapa tujuan lainnya yang mereka miliki dan belum tentu mereka dapat dari tempat asalnya. Maka dari itu, perjalanan yang dilakukan oleh seseorang dapat dipengaruhi oleh beberapa faktor yaitu faktor pendorong dan faktor penarik.

Faktor pendorong dan faktor penarik bisa juga dikatakan sebagai faktor internal/dalam diri seseorang dan eksternal/luar diri seseorang yang memotivasi wisatawan untuk berkunjung ke daya tarik wisata. Menurut Ryan dalam Pitana, 2005:67 menyatakan faktor pendorong bagi seseorang untuk melakukan perjalanan wisata yaitu; (1) escape, (2) relaxation, (3) play, (4) strengthening family bonds, (5) prestige, (6) social interaction, (7) romance, (8) educational opportunity, (9) selffulfilment dan (10) wish-fulfilment. Sedangkan faktor penarik menurut Jackson dalam Pitana, 2005:68 yakni; (1) location elimate, (2) national promotion, (3) retail advertising, (4) wholesale marketing, (5) special events, (6) incentive schemes, (7) visiting friends, (8) visiting relatives, (9) tourist attraction, (10) culture dan (11) natural environment manmade environment.

Bali merupakan salah satu destinasi wisata yang dimiliki oleh Negara Indonesia. Pulau Bali memiliki begitu banyak daya tarik wisata yang diminati oleh wisatawan baik lokal maupun mancanegara. Daya tarik wisata yang dimiliki Bali seperti tradisi, adat-istiadat yang unik, budaya, keindahan alam dan lainlain. Daya tarik wisata ini juga didukung oleh sarana dan prasarana seperti hotel, villa, homestay, restoran, rumah makan, pelabuhan, bandar udara, transportasi dan lain-lain.

Bali dijuluki sebagai "Pulau Seribu Pura", terdiri atas: pura keluarga dan klan, pura desa dan kerajaan, pura gunung dan danau, hutan dan sumber air yang kesemuanya merupakan rekaman nyata akan sejarah Bali. 
(Picard, 2006 : 16). Beberapa dari pura di Bali menjadi salah satu daya tarik wisata yang diminati oleh wisatawan. Lebih lanjut, Belanda memperkenalkan Bali kepada turis mancanegara dengan menggunakan ikon "The Island Of Thousand Temples" dan "The Last Paradise". Berkat promosi yang dilakukan oleh Belanda, maka Bali semakin diminati untuk dikunjungi oleh turis dari Eropa dan Amerika. Wisatawan mancanegara mulai berdatangan untuk melihat langsung keunikan tradisi budaya, eksotisme alam pedesaan Bali, candi (pura) peninggalan arkeologis zaman Bali Kuno. (Sendra, 2016 : 116).

Bali terkenal dengan wisata budayanya. Wisata budaya adalah perjalanan yang dilakukan atas dasar keinginan untuk memperluas pengetahuan dan pengalaman seseorang dengan cara melakukan kunjungan atau peninjauan ke tempat lain atau ke luar negeri. Hal ini bertujuan untuk mengetahui keadaan rakyat di suatu wilayah, mengetahui kebiasaan atau adat istiadat, cara hidup, serta mempelajari budaya dan keseniannya. Wisatawan dapat melakukan sesuatu di daerah tujuan wisata seperti ikut terlibat dalam kegiatan-kegiatan budaya daerah yang dikunjungi, seperti eksposisi seni (seni tari, drama, musik dan seni suara), atau kegiatan yang bermotif kesejarahan dan sebagainya. (Utama, 2017 : 145-146). Wisatawan yang melakukan kunjungan kesuatu daerah tujuan wisata dapat melihat keindahan arsitektur bangunan Bali dan pura - pura. Selain itu wisatawan dapat membeli kerajinan tangan yang dibuat oleh masyarakat lokal.

Bali memiliki 8 (delapan) kabupaten, salah satunya yaitu Kabupaten Gianyar. Gianyar sebagai kota seni terkenal dengan daya tarik wisata budayanya. Menurut Perda No. 16 Tahun 2012 Tentang Rencana Tata Ruang Wilayah Kabupaten Gianyar pasal 52 ayat 1 yang menyatakan bahwa "Kota Gianyar memiliki beberapa daya tarik wisata budaya, antara lain: Desa Celuk, Desa Batuan dan Desa Batubulan di Kecamatan Sukawati. Puri Agung Gianyar, Kelurahan Gianyar di Kecamatan Gianyar. Desa Mas, Desa Peliatan, Kelurahan Ubud, Museum Rudana, Museum Neka, Museum Ratna Warta/Puri Lukisan dan Museum Arma di Kecamatan Ubud."

Salah satu daya tarik wisata budaya yang dimiliki oleh Kabupaten Gianyar yaitu Desa Batuan. Desa ini memiliki berbagai kesenian seperti seni pahat, seni patung, seni tari, seni lukis dan lain-lain. Selain kaya akan keseniannya, Desa Batuan memiliki beberapa daya tarik wisata, salah satunya yaitu Pura Puseh Pura Desa Adat Batuan. Pura Puseh Desa Batuan ini merupakan salah satu pura tertua yang ada di Bali yang dibangun pada 944 Ḉaka atau 1022 Masehi.

Pura ini mempunyai desain yang artistik. Keindahan ornamen yang terdapat pada pura ini dan benda purbakala yang ada di dalamnya merupakan daya tarik serta menjadi keunikan tersendiri bagi wisatawan yang berkunjung. Pura Puseh Batuan merupakan bagian dari Kahyangan Tiga yang lazim dimiliki oleh setiap desa pakraman di Bali. Di dalam pura, terdapat peninggalan beberapa benda purbakala berbentuk arca seperti: (a) Arca Dwarepala yaitu patung penjaga pintu atau gerbang dalam ajaran Siwa dan Buddha. Arca ini terletak di luar pura yaitu sebelah barat pura dan sebelah timur pura, (b) Arca perwujudan yakni patung Siwa, patung Buddha, Dewi Sri, Persimpangan Balang Tamak, Ratu Slimpet, Dedari, Ratu Pande, Ratu Saung, Naga Basukian dan manusia memegang ayam, (c) Arca binatang seperti gajah, beruang, singa, dan empas (kura-kura besar), (d) Lingga yoni simbol Siwa dan saktinya sebagai lambang kemakmuran, lumbung, lesung, ceraki (tempat untuk memberi makan kepada masyarakat zaman dulu).

Pura Puseh Pura Desa Adat Batuan ini memiliki luas kurang lebih 1,5 hektar. Pura Puseh Pura Desa Adat Batuan memiliki dua wantilan. Wantilan pura yang pertama berada diluar areal pura yang terletak diseberang jalan tepat di depan pintu masuk pura. Pada wantilan pertama terdapat beberapa warung kecil dan toilet. Selain itu juga tersedia area parkir untuk wisatawan. Wantilan pura yang kedua terletak di sebelah barat pura, di wantilan ini terdapat area parkir yang tidak begitu luas dan beberapa warung kecil yang dikelola dan dimiliki oleh masyarakat lokal. Di setiap wantilan yang dimiliki pura ini, terdapat tempat untuk mengambil sarung yang harus digunakan oleh wisatawan yang ingin memasuki area pura. Wisatawan yang dilarang memasuki area pura yaitu wisatawan perempuan yang sedang dalam kondisi datang bulan.

Pura ini memiliki fungsi yang sama dengan pura - pura lain yang ada di Bali. Fungsi dari pura yaitu untuk memuja dalam 
manifestasiNya sebagai pencipta dan pemelihara. Dalam ajaran agama Hindu, Pura Puseh Pura Desa merupakan bagian dari penerapan Kahyangan Tiga yang merupakan tiga pura yang wajib di bangun di setiap desa pakraman yang ada di Bali. Ketiga pura tersebut, yakni Pura Puseh untuk menyembah Dewa Wisnu sebagai pemelihara alam semesta, Pura Desa untuk menyembah Dewa Brahma sebagai pencipta alam semesta dan Pura Dalem yaitu pura untuk menyembah Dewa Siwa sebagai dewa pelebur. Namun, yang membedakan Pura Puseh Pura Desa Adat Batuan dengan pura khayangan tiga lainnya yaitu pura ini memiliki peninggalan bersejarah yang terletak di dalam area pura yang belum tentu ada disetiap pura khayangan tiga lainnya. Berbagai peninggalan zaman kuno ini membuat wisatawan tertarik untuk mengunjunginya.

Awal mula adanya kegiatan pariwisata di Desa Batuan dimulai pada tahun 1980'an. Pada saat itu belum ada pengelola pura sebagai daya tarik wisata. Ketertarikan wisatawan terhadap pura ini berawal dari wisatawan berkunjung ke Desa Batuan untuk belanja ke artshop. Namun, ketika melihat adanya pura ini wisatawan tertarik akan Pura Puseh Pura Desa Adat Batuan, Gianyar, dan hingga kini menjadi daya tarik wisata.

Tahun 2006, pengelolaan Pura Puseh

Pura Desa Adat Batuan menjadi lebih efektif dan kegiatan kepariwisataan di Pura Puseh Pura Desa Adat Batuan ini juga melibatkan masyarakat lokal. Wisatawan yang berkunjung ke pura ini lebih diminati oleh wisatawan mancanegara seperti China, India, Jepang, Korea, Eropa, Spanyol, Belanda, Denmark, Prancis, Australia, Italia, Irish, dan lain - lain.

Tabel 1 akan menjelaskan data kunjungan wisatawan di Pura Puseh Pura Desa Adat Batuan, Gianyar pada tahun 2012 - 2016. Data kunjungan wisatawan dilihat dari berapa banyak wisatawan dalam buku kunjungan yang melakukan donasi saat mereka berkunjung ke pura ini.

Tabel 1

Data Kunjungan Wisatawan Mancanegara Ke Pura Puseh Pura Desa Adat Batuan Tahun 2012-2016

\begin{tabular}{cccc}
\hline No & Tahun & $\begin{array}{c}\text { Jumlah } \\
\text { Kunjungan }\end{array}$ & $\begin{array}{c}\text { Pertumbuhan } \\
\mathbf{( \% )}\end{array}$ \\
\hline 1 & 2012 & 4.730 & - \\
\hline
\end{tabular}

\begin{tabular}{cccc}
\hline 2 & 2013 & 4.202 & $-11,16 \%$ \\
\hline 3 & 2014 & 5.183 & $23,34 \%$ \\
\hline 4 & 2015 & 5.799 & $11,88 \%$ \\
\hline 5 & 2016 & 5.337 & $-7,96 \%$ \\
\hline & Rerata & $\mathbf{5 . 0 5 0}$ & \\
\hline
\end{tabular}

Sumber: Data Kunjungan Wisatawan Pura Puseh Pura Desa Adat Batuan, 2016

Berdasarkan Tabel data kunjungan wisatawan yang berkunjung ke Pura Puseh Pura Desa Adat Batuan diatas maka dapat disimpulkan bahwa pada tahun 2012 jumlah kunjungan wisatawan sebesar 4.730, lanjut pada tahun 2013 mengalami penurunan dengan jumlah kunjungan sebesar 4.202 dengan pertumbuhan $-11,16 \%$. Pada tahun 2014 mengalami peningkatan dengan jumlah kunjungan sebesar 5.183 dengan pertumbuhan 23,34\%. Pada tahun 2015 kembali mengalami peningkatan dengan jumlah kunjungan sebesar 5.799 dengan pertumbuhan $11,88 \%$, namun pada tahun 2016 mengalami penurunan dengan jumlah kunjungan sebesar 5.337 dengan pertumbuhan $-7,69 \%$. Rata-rata jumlah kunjungan wisatawan dari tahun 2012-2016 sebesar 5.050. Dari data kunjungan wisatawan tersebut diatas bahwa perkembangan data kunjungan dari tahun 2012 - 2016 mengalami fluktuasi.

Hal ini menjadi salah satu alasan untuk dilakukan penelitian di Pura Puseh Pura Desa Adat Batuan, Gianyar. Adapun permasalahan dalam penelitian ini antara lain potensi yang dimiliki oleh Pura Puseh Pura Desa Adat Batuan, Gianyar dan faktor - faktor yang mempengaruhi motivasi wisatawan mancanegara berkunjung ke Pura Puseh Pura Desa Adat Batuan, Gianyar.

\section{METODE PENELITIAN}

Lokasi penelitian dilakukan di Pura Puseh Pura Desa Adat Batuan Kecamatan Gianyar Kabupaten Gianyar, Bali. Letak pura ini sangat strategis dan mudah di akses. Peneliti memilih lokasi penelitian di Pura Puseh Pura Desa Adat Batuan Gianyar karena pura ini merupakan salah satu Cagar Budaya Bali.

Adapun variabel yang diteliti dalam penelitian ini yaitu variabel motivasi. Variabel ini dibagi menjadi dua sub-variabel, yaitu faktor pendorong dan faktor penarik. Faktor pendorong dalam penelitian ini dibagi menjadi 
empat indikator yaitu: a) motivasi fisik, b) motivasi fantasi, c) motivasi sosial, d) promosi. Faktor penarik dalam penelitian ini dibagi menjadi empat indikator yaitu: a) atraksi wisata, b) motivasi budaya, c) education, d) accessibility.

Teknik pengumpulan data yang digunakan dalam penelitian ini yaitu: 1) Observasi yaitu pengumpulan data dengan cara pengamatan langsung ke lokasi penelitian di Pura Puseh Pura Desa Adat Batuan Gianyar serta mengamati kegiatan yang dilakukan oleh wisatawan di dalam pura, 2) Wawancara mendalam teknik pengumpulan data yang berupa mendapatkan informasi dari informan selaku pengelola di Pura Puseh Pura Desa Adat Batuan, Gianyar. Wawancara mendalam yang dilakukan kepada pihak yang mengetahui gambaran umum mengenai Desa Batuan dan Pura Puseh Pura Desa Adat Batuan serta potensi-potensi yang dimiliki oleh Pura Puseh Pura Desa Adat Batuan, 3) Kuesioner dengan skala likert, 4) Studi kepustakaan yaitu pengumpulan data dengan menggunakan berbagai buku atau literatur - literatur yang berkaitan dengan penelitian ini dan dapat mendukung kelengkapan dari penelitian ini, 5) Dokumentasi yaitu teknik pengumpulan data yang berupa arsip-arsip atau foto-foto yang didapatkan pada saat melakukan observasi di lokasi penelitian.

Adapun teknik penentuan informan yang digunakan dalam penelitian ini yaitu teknik penentuan informan pangkal dan informan kunci. Dalam penelitian ini, yang menjadi informan pangkal adalah Bendesa Adat Batuan dan informan kunci dalam penelitian ini yaitu informan yang direkomendasikan oleh Bendesa Adat Batuan seperti pengelola pura.

Adapun penentuan sampel dalam penelitian ini yaitu dengan menggunakan accidental sampling, dengan sampel 108 responden. Responden yang diambil dalam penelitian ini yaitu wisatawan mancanegara yang berkunjung ke Pura Puseh Pura Desa Adat Batuan, Gianyar.

Teknik analisis data yang digunakan dalam penelitian ini yaitu deskriptif kuantitatif, uji validitas, uji reliabilitas dan analisis faktor dengan bantuan program SPSS Versi 17.0.

\section{HASIL DAN PEMBAHASAN}

Desa Batuan terkenal akan kesenian dan kerajinannya. Hampir setiap masyarakat yang berada di dusun Desa Batuan bermata pencaharian sebagai pengrajin. Kerajinan yang dihasilkan yaitu kerajinan ukir, patung, tapel barong dan rangda, kursi, meja, lukisan, pernak-pernik dari kaca dan lain-lain. Selain dari hasil kerajinan tangan Desa Batuan memiliki beberapa daya tarik wisata. Salah satu daya tarik wisata yang dimiliki yaitu Pura Puseh Pura Desa Adat Batuan, Gianyar. Pura Puseh Pura Desa Adat Batuan ini merupakan salah satu pura tertua yang ada di Bali. Sejarah berdirinya pura, menurut prasasti pura ini dibangun pada 944 Ḉaka atau 1022 Masehi.

Pura Puseh Pura Desa Adat Batuan merupakan salah satu cagar budaya yang dilindungi oleh Dinas Kebudayaan. Di dalam pura ini terdapat peninggalan purbakala berasal dari masa prasejarah yang tersimpan dengan baik.

Wisatawan yang ingin berkunjung ke Pura Puseh Pura Desa Adat Batuan, Gianyar dapat melakukan donasi yang dimasukkan kedalam kotak donation yang berada di wantilan pura atau kotak donasi yang diletakkan di dalam pura. Donasi yang dilakukan oleh wisatawan dapat diberikan secara suka rela. Donasi ini digunakan untuk membantu biaya perawatan pura. Potensipotensi yang dimiliki oleh Pura Puseh Pura Desa Adat Batuan, Gianyar antara lain:

Peninggalan Bersejarah/Peninggalan Purbakala. Di dalam pura ini terdapat peninggalan purbakala yang terletak di belakang bangunan pura. Pura Puseh Pura Desa Adat Batuan ini telah menjadi cagar budaya yang dilindungi oleh Undang-Undang Nomor 11 Tahun 2010 Tentang Cagar Budaya.

Peninggalan bersejarah yang terdapat di pura ini menjadi salah satu daya tarik wisata bagi wisatawan yang berkunjung. Berbagai jenis wisatawan mancanegara berkunjung ke pura ini, tidak sedikit dari wisatawan mengambil foto - foto benda kuno tersebut dengan kamera yang mereka bawa.

Jenis-jenis peninggalan purbakala yang tersimpan yakni: a) Arca Dwarepala adalah patung penjaga pintu atau gerbang dalam ajaran Siwa dan Buddha. Arca ini terletak di luar pura yaitu sebelah barat pura dan sebelah timur pura dekat dengan jalan raya, b) Arca perwujudan yakni patung Siwa, patung Buddha, Dewi Sri, Persimpangan Balang Tamak, Ratu Slimpet, Dedari, Ratu Pande, Ratu Saung, Naga Basukian dan manusia memegang ayam, c) Arca binatang seperti gajah, beruang, singa, dan 
empas (kura-kura besar), d) Lingga \& Yoni simbol Siwa dan saktinya sebagai lambang kemakmuran, lumbung, lesung, ceraki.

Singkat cerita awal mula adanya peninggalan bersejarah di pura ini yaitu pada zaman dahulu pada masa kerajaan Bedahulu terdapat pepatih yang bernama Kebo Iwa yang berasal dari Desa Blahbatuh. Pepatih Kebo Iwa inilah yang membuat patung-patung tersebut di dalam pura dengan kuku beliau, yang hingga saat ini tersimpan sebagai peninggalan purbakala.

Potensi wisata yang dimiliki selanjutnya yaitu Rejang Sutri. Rejang Sutri merupakan tarian yang dipentaskan oleh masyarakat di Desa Batuan yang diselenggarakan di wantilan Pura Puseh Pura Desa Adat Batuan setiap satu tahun sekali. Tarian Rejang Sutri diadakan pada Sasih Kelima pada bulan November sampai Sasih Kesanga pada bulan Maret setiap hari dimalam hari. Tarian ini selesai di pentaskan saat Gembak Geni sehari setelah Hari Raya Nyepi.

Sejarah munculnya tari Rejang Sutri di desa Batuan sangat sulit untuk didefinisikan, hal ini dikarenakan tidak ada catatan sejarah ataupun literatur-literatur mengenai sejarah tarian Rejang Sutri. Namun, terdapat sebuah cerita rakyat yang secara turun temurun telah dipercayai oleh masyarakat Batuan mengenai sejarah dari tarian ini. Cerita tersebut adalah berawal dari kekalahan I Renggan yang sekarang bergelar Ratu Gede Mecaling yang menguasai ilmu hitam atas I Dewa Babi mengakibatkan terciptanya tarian Rejang Sutri tersebut.

Dikisahkan bahwa I Renggan selalu membuat resah penduduk Desa Batuan dengan ilmu hitamnya yang selalu berbuat jahat. Salah satu hal yang dilakukan oleh I Renggan yaitu suka menghidupkan kembali babi yang sudah diguling atau dipanggang oleh masyarakat yang digunakan sebagai sesajen untuk upacara agama. Masyarakat menjadi resah dan melaporkannya kepada Dewa Babi. Dewa Babi memutuskan untuk mengajak I Renggan bertarung mengguling atau memanggang babi.

Diceritakan bahwa I Renggan kalah dalam pertandingan dan dia harus pergi dari Desa Batuan, sehingga dia tinggal di Jungut Batu, Nusa Penida, Kabupaten Klungkung. Di Nusa Penida ia bernama Ratu Gede Mecaling. Ratu Gede Mecaling berjanji akan mencari tumbal di Desa Batuan, serta siapapun yang berani datang ke Nusa Penida akan mendapatkan celaka, karena hal itu warga menjadi resah.

Pemangku menyiasati agar pada saat sasih kalima pada bulan November sampai Sasih Kesanga pada bulan Maret masyarakat tidur di bawah tempat tidur. Hal ini bertujuan agar masyarakat terlihat seperti babi. Namun, setelah sekian lama melakukan hal tersebut, masyarakat merasa jenuh dengan baying bayang Ratu Gede Mecaling, sehingga sesuunan atau Dewa yang berstana di Pura Puseh Pura Desa Adat Batuan memberikan pemberitahuan atau sabda kepada pemangku agar menyuguhkan sebuah tarian Rejang Sutri dan Gocekan Ayam (sambung ayam). Sebab dengan melakukan hal itu, maka dapat meluluhkan hawa nafsu dan dendam yang dirasakan oleh Ratu Gede Mecaling.

Rejang sutri menjadi salah satu daya tarik tersendiri bagi wisatawan. Wisatawan datang ke pura untuk menonton tarian yang dipentaskan. Selain itu ada wisatawan perempuan ikut serta menari dengan menggunakan sarung yang sudah disediakan di pura dan wisatawan mengabadikan momen mereka disana.

Potensi wisata yang terakhir yaitu Gocekan Ayam. (Gocekan ayam (sambung ayam) diadakan setiap hari dari Sasih Kelima pada bulan November sampai Sasih Kesanga pada bulan Maret. Gocekan ayam diselenggarakan di dalam area pura yang dilaksanakan oleh masyarakat Desa Batuan. Gocekan ini hanya diadakan di siang hari dan pada malam harinya dilanjutkan dengan pementasan Rejang Sutri. Gocekan aym memiliki sejarah yang sama dengan Rejang Sutri. Wisatawan yang berkunjung ke pura ini ikut serta menonton sambung ayam dan mengabadikan momen tersebut.

Berdasarkan hasil karakteristik responden dalam penelitian ini wisatawan perempuan lebih mendominasi daripada wisatawan laki-laki. Wisatawan perempuan sebanyak $69 \%$ dan wisatawan laki-laki sebanyak 31\%. Berdasarkan umur wisatawan, didominasi oleh wisatawan berumur 25-44 tahun. Jumlah wisatawan mancanegara berumur 15-24 tahun mencapai $31 \%$, wisatawan berumur 25-44 tahun mencapai 52\%, wisatawan berumur 45-64 tahun mencapai 14\%, dan wisatawan berumur $>65$ tahun mencapai $3 \%$. Apabila dilihat dari jumlah persentasenya yang lebih dominan berkunjung yaitu wisatawan mancanegara berumur 25-44 tahun. 
Selanjutnya, berdasarkan negara asal wisatawan dalam penelitian ini Negara Australia sebesar 24\%, Italian sebesar 2,7\%, Belanda sebesar 13\%, French sebesar 6,4\%, Austria sebesar 1,9\%, China sebesar 5,6\%, Thailand sebesar $1,9 \%$, USA sebesar $4,6 \%$, Denmark sebesar 4,6\%, German sebesar $12 \%$, Irish sebesar 5,5\%, Slovenian sebesar 1\%, Switzerland sebesar 2,7\%, British sebesar $11,1 \%$, Canadian sebesar 1\%. Polish sebesar 1\%, dan Danish sebesar 1\%. Apabila dilihat dari persentasenya maka negara asal wisatawan yang mendominasi adalah Negara Australia.

Tahapan analisis faktor yaitu dilakukan dengan menentukan jumlah indikator. Adapun jumlah indikator dalam penelitian ini yaitu 18 indikator. Selanjutnya uji kelayakan Bartlett's Test of Sphericity pada signifikan $>0,5$ menunjukkan hubungan antara indikator indikator tersebut signifikan. Hasil Bartlett's Test of Sphericity dalam penelitian ini yaitu 1067.319. Selanjutnya uji Kaiser Mayer Olkin (KMO) dengan kriteria KMO > 0,5, untuk hasil uji Kaiser Mayer Olkin (KMO) dalam penelitian ini yaitu 0,866 maka dapat disimpulkan bahwa sampel dalam penelitian ini layak dan dapat mengikuti langkah selanjutnya.

Tahapan selanjutnya yaitu uji Measure Sampling Adequency (MSA) dengan kriteria MSA > 0,5 menunjukan derajat korelasi antar indikator saling berhubungan erat. Hasil MSA 18 indikator dalam penelitian ini memenuhi kriteria sehingga dapat lanjut ketahap berikutnya.

Tahapan selanjutnya yaitu proses faktor yang terbentuk dalam penelitian ini dari 18 indikator menjadi 3 faktor dengan total cumulative of variance sebesar $61,092 \%$. Hal ini menunjukkan ketiga faktor tersebut mampu menjelaskan faktor sebesar 61,092\% total varian faktor-faktor yang mempengaruhi wisatawan mancanegara berkunjung ke Pura Puseh Pura Desa Adat Batuan, Gianyar.

Tahapan selanjutnya yaitu rotasi faktor dengan syarat factor loading $>0,5$. Berdasarkan 18 indikator dalam penelitian ini mendapatkan hasil factor loading lebih besar dari 0,5 .

Berdasarkan hasil rotasi varimax pada Tabel 2 dapat dilihat bahwa terdapat 3 (tiga) faktor yang mempengaruhi motivasi wisatawan mancanegara berkunjung ke Pura Puseh Pura Desa Adat Batuan, Gianyar. Ketiga faktor tersebut kemudian diinterpretasikan atau dikelompokkan.

\begin{tabular}{|c|c|c|c|c|c|}
\hline No & $\begin{array}{l}\text { Nama } \\
\text { Variabel }\end{array}$ & Faktor & $\begin{array}{l}\text { Eigen } \\
\text { Value }\end{array}$ & $\begin{array}{l}\text { Factor } \\
\text { Loading }\end{array}$ & $\begin{array}{l}\text { Percent of } \\
\text { Variance }\end{array}$ \\
\hline 1 & $\begin{array}{l}\text { Keunikan } \\
\text { Budaya }\end{array}$ & 1 & 6,998 & 0,840 & 38,879 \\
\hline 2 & $\begin{array}{l}\text { Peninggalan } \\
\text { Bersejarah }\end{array}$ & & & 0,832 & \\
\hline 3 & Kesenian & & & 0,831 & \\
\hline 4 & Adat Istiadat & & & 0,810 & \\
\hline 5 & $\begin{array}{l}\text { Pengalaman } \\
\text { Baru }\end{array}$ & & & 0,755 & \\
\hline 6 & Kenyamanan & & & 0,627 & \\
\hline 7 & $\begin{array}{l}\text { Melihat } \\
\text { masyarakat } \\
\text { lokal } \\
\text { membuat } \\
\text { canang sari } \\
\text { dan sesajen }\end{array}$ & & & 0,624 & \\
\hline 8 & $\begin{array}{l}\text { Mudah } \\
\text { Diakses }\end{array}$ & & & 0,560 & \\
\hline 9 & $\begin{array}{l}\text { Kepuasan } \\
\text { Psikologis }\end{array}$ & & & 0,517 & \\
\hline 1 & $\begin{array}{l}\text { Pengaruh } \\
\text { Keluarga }\end{array}$ & 2 & 2,814 & 0,815 & 15,633 \\
\hline 2 & $\begin{array}{l}\text { Pengaruh } \\
\text { rekan kerja }\end{array}$ & & & 0,815 & \\
\hline 3 & $\begin{array}{l}\text { Informasi } \\
\text { dari travel } \\
\text { agent }\end{array}$ & & & 0,738 & \\
\hline 4 & $\begin{array}{l}\text { Informasi } \\
\text { dari internet }\end{array}$ & & & 0,735 & \\
\hline 1 & Gengsi & 3 & 1,184 & 0,639 & 6,579 \\
\hline 2 & Struktur Pura & & & 0,596 & \\
\hline 3 & $\begin{array}{l}\text { Interaksi } \\
\text { Sosial }\end{array}$ & & & 0,593 & \\
\hline 4 & $\begin{array}{l}\text { Pengaruh } \\
\text { Teman }\end{array}$ & & & 0,567 & \\
\hline 5 & Escape & & & 0,535 & \\
\hline
\end{tabular}

Faktor 1 diberi nama faktor penarik dengan nilai eigen value 6,998. Faktor ini menjelaskan bahwa keragamanan variabel sebesar 38,879 \% dari tiga faktor yang ditemukan, faktor penarik merupakan faktor yang memiliki varian yang lebih besar dari faktor lainnya, sehingga dapat ditarik kesimpulan bahwa faktor penarik merupakan faktor yang berkontribusi lebih dominan dalam mempengaruhi motivasi wisatawan mancanegara berkunjung ke Pura Puseh Pura Desa Adat Batuan, Gianyar. Apabila dilihat dari loading factor setiap indikator, maka faktor penarik berasal dari variabel faktor penarik dengan indikator yang berasal dari motivasi budaya meliputi: a) keunikan budaya merupakan indikator yang mewakili faktor penarik dengan loading factor sebesar 0,840; b) peninggalan bersejarah dengan loading factor sebesar 0,832; c) kesenian dengan loading factor sebesar 0,831 ; d) adat istiadat dengan loading factor sebesar 0,810 .

Selanjutnya variabel faktor pendorong dengan indikator motivasi fantasi yaitu pengalaman baru dengan loading factor sebesar 0,755 . Selanjutnya variabel faktor pendorong dengan indikator motivasi fisik yaitu kenyamanan dengan loading factor sebesar 0,627 . Selanjutnya variabel faktor penarik dengan indikator atraksi wisata yaitu melihat masyarakat lokal membuat canang sari dan 
sesajen dengan loading factor sebesar 0,624. Selanjutnya variabel faktor penarik dengan indikator accessibility yaitu mudah diakses dengan loading factor sebesar 0,560, serta yang terakhir yaitu variabel faktor pendorong dengan indikator motivasi fantasi yaitu kepuasan psikologis dengan loading factor sebesar 0,517. Faktor pertama diberi nama faktor penarik disebabkan karena pada faktor ini variabel faktor penarik lebih dominan daripada faktor pendorong.

Faktor 2 diberi nama faktor promosi dengan nilai eigen value sebesar 2,814. Faktor promosi berasal dari variabel pendorong dengan indikator promosi sehingga faktor dua diberi nama faktor promosi. Faktor-faktor ini menjelaskan keragaman dari indikator dengan nilai variance sebesar 15,633 \%. Apabila dilihat dari loading factornya, maka pengaruh keluarga dengan loading factor sebesar 0,815, pengaruh rekan kerja sebesar 0,815 , informasi dari travel agent dengan loading factor sebesar 0,738 , serta informasi dari internet dengan loading factor sebesar 0,735 .

Faktor 3 diberi nama faktor pendorong dengan nilai eigen value sebesar 1,184. Faktorfaktor ini menjelaskan keragaman dari indikator dengan nilai variance sebesar $6,579 \%$. Faktor tiga lebih dominan berasal dari variabel pendorong sehingga diberi nama dengan faktor pendorong. Apabila dilihat dari loading factornya variabel berasal dari variabel pendorong dengan indikator motivasi sosial meliputi: gengsi dengan loading factor sebesar 0,639 . Variabel faktor penarik dengan indikator edukasi meliputi: struktur pura dengan loading factor sebesar 0,596. Variabel faktor pendorong dengan indikator motivasi sosial meliputi: interaksi sosial dengan loading factor sebesar 0,593 . Variabel faktor pendorong dengan indikator promosi meliputi: pengaruh teman dengan loading factor sebesar 0,567 , serta yang terakhir dari variabel pendorong dengan indikator motivasi fisik meliputi: escape dengan loading factor sebesar 0,535.

\section{SIMPULAN}

Pura Puseh Pura Desa Adat Batuan adalah salah satu daya tarik wisata yang masih terdapat di dalam kawasan Desa Adat Batuan di Dusun Tengah, Desa Batuan, Kecamatan Sukawati, Kabupaten Gianyar. Pura ini merupakan salah satu pura tertua yang ada di Bali. Sejarah berdirinya pura ini menurut prasasti dibangun pada 944 Çaka atau 1022 Masehi. Pura Puseh Pura Desa Adat Batuan merupakan salah satu cagar budaya yang menyimpan peninggalan purbakala berasal dari masa prasejarah.

Wisatawan yang berkunjung ke Pura Puseh Pura Desa Adat Batuan, Gianyar lebih didominasi oleh wisatawan dengan jenis kelamin perempuan sebesar 69\%. Berdasarkan umur wisatawan yang berkunjung ke pura ini didominasi oleh wisatawan berumur 25-44 tahun. Negara asal wisatawan mancanegara yang berkunjung ke pura ini yaitu negara Australia.

Potensi-potensi yang dimiliki oleh Pura Puseh Pura Desa Adat Batuan, Gianyar adalah potensi budaya yaitu: 1) Peninggalan bersejarah/peninggalan purbakala. Pura Puseh Pura Desa Adat Batuan ini telah menjadi cagar budaya yang dilindungi oleh Undang-Undang Nomor 11 Tahun 2010 Tentang Cagar Budaya.

Jenis-jenis peninggalan purbakala yang tersimpan yakni: a) Arca Dwarepala yaitu patung penjaga pintu atau gerbang dalam ajaran Siwa dan Buddha. Arca ini terletak di luar pura yaitu sebelah barat pura dan sebelah timur pura dekat dengan jalan raya, b) Arca perwujudan yakni patung Siwa, patung Buddha, Dewi Sri, Persimpangan Balang Tamak, Ratu Slimpet, Dedari, Ratu Pande, Ratu Saung, Naga Basukian dan manusia memegang ayam, Arca binatang seperti gajah, beruang, singa, dan empas (kura-kura besar), c) Lingga \& Yoni simbol Siwa dan saktinya sebagai lambang kemakmuran, lumbung, lesung, ceraki. 2) Rejang Sutri merupakan tarian yang dipentaskan oleh masyarakat di Desa Batuan yang diselenggarakan di wantilan Pura Puseh Pura Desa Adat Batuan setiap satu tahun sekali. Tarian Rejang Sutri diadakan pada Sasih Kelima pada bulan November sampai Sasih Kesanga pada bulan Maret setiap hari dimalam hari. Tarian ini selesai di pentaskan saat Gembak Geni sehari setelah Hari Raya Nyepi. 3) Gocekan ayam (sambung ayam), yang diadakan setiap hari dari Sasih Kelima pada bulan November sampai Sasih Kesanga pada bulan Maret.

Berdasarkan urutan dari penelitian faktor-faktor yang mempengaruhi motivasi wisatawan mancanegara berkunjung ke Pura Puseh Pura Desa Adat Batuan, Gianyar sebagai berikut: 1) Faktor penarik meliputi: Keunikan budaya, Peninggalan bersejarah, Kesenian, Adat istiadat, Pengalaman baru, Kenyamanan, 
Melihat masyarakat lokal membuat canang sari dan sesajen, Mudah diakses, Kepuasan psikologis. 2) Faktor Promosi meliputi: Pengaruh keluarga, Pengaruh rekan kerja, Informasi dari travel agent, Informasi dari internet. 3) Faktor Pendorong meliputi: Gengsi, Struktur pura, Interaksi sosial, Pengaruh teman, Escape.

\section{SARAN}

Berdasarkan hasil penelitian dan pembahasaan diatas maka dapat dikemukakan saran kepada peneliti selanjutnya agar mengambil penelitian dengan permasalahan yang berbeda, yaitu menelaah lebih lanjut mengenai karakteristik wisatawan dan pengambilan keputusan wisatawan, serta wisatawan apa yang lebih dominan berkunjung ke Pura Puseh Pura Desa Adat Batuan.

Selanjutnya saran untuk pengelola pura agar lebih ketat menjaga dan memantau wisatawan yang berada di dalam pura. Hal ini bertujuan untuk menghindari terjadinya kerusakan pada benda - benda kuno yang diakibatkan oleh wisatawan yang sedang berkunjung.

Saran selanjutnya yaitu perlu adanya guide lokal di dalam pura untuk memandu wisatawan yang berkunjung. Selain itu, perlu disediakan buku tentang sejarah pura dan budaya masyarakat lokal, agar memudahkan wisatawan khususnya wisatawan yang tidak membawa guide untuk mengetahui informasi mengenai Pura Puseh Pura Desa Adat Batuan, Gianyar. 


\section{Kepustakaan}

Perda. 2012. Peraturan Daerah Pemerintah Kabupaten Gianyar Nomor 16 Tahun 2012 Tentang Rencana Tata RuangWilayah (RTRW). Kabupaten Gianyar. Bali.

Picard, Michel. 2006. Bali: Pariwisata Budaya dan Budaya Pariwisata.

Jakarta:Perpusatakaan Populer Gramedia.

Pitana, I Gde dan Putu G. Gayatri. 2005. Sosiologi Pariwisata.Yogyakarta: Andi.

Rai Utama, I Gst Bagus. 2017. Pemasaran Pariwisata. Yogyakarta:CV Andi

Sendra, I Made. 2014. Paradigma Kepariwisataan Bali Tahun 1930-an: Studi Genealogi Kepariwisataan Budaya. Jurnal Kajian Bali Vol. 06, No. 02 .

Widyastuti, NI Kadek. Waruwu, Darmawan dan Suartana, I Ketut.2017. Pariwisata Spiritual Daya Tarik Wisata Pulasari Bali. Denpasar: Pustaka Larasan. 